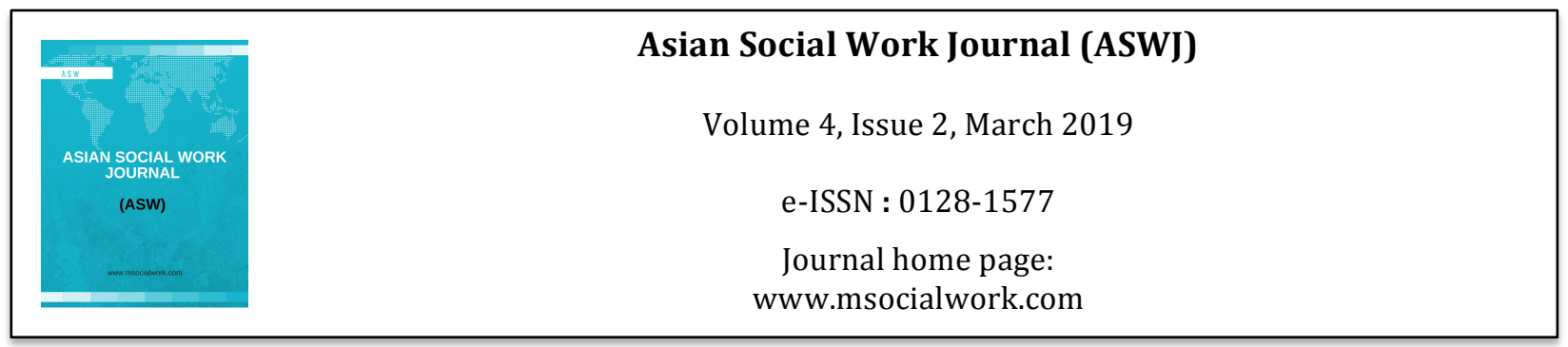

\title{
Social Mapping of Clean and Healthy Life Behavior of Remote Indigenous Communities in Kampung Ulakin Kolf Brasa District Asmat Regency Papua Province
}

\author{
Urip Wahyudin 1 \\ 1Faculty of Social and Political Sciences, University of Cendrawasih, Jayapura, Papua \\ Corrrespondence: Urip Wahyudin (wahyudinkaliacai@gmail.com)
}

\begin{abstract}
This social mapping aims to collect data and information about clean and healthy life behavior (PHBS) of Remote Indigenous Communities (KAT) in Ulakin Village, Kolf Brasa District, Asmat Regency, Papua Province. The method of data collection in this study is survey method. Data collection techniques used; 1) observation, 2) interviews with leaders and community members, and 3) focus group discussions. The results of the study show that; 1) childbirth assistance has not been carried out by health workers, 2) babies have been breastfed, 3) the community does not have health insurance, 4) the community still utilizes the availability of rainwater and rivers, 5) some houses have used healthy toilets as facilities from the local government, but not yet utilized as appropriate, 6) the average floor area of a house is $36 \mathrm{~m} 2$ with an average occupant of 3-5 people, 7) the floor of the house is made of wooden boards which are assistance from the government, 8) the community still smokes in any place, including inside the house, 9) the community always engages in physical activities in the context of hunting and gathering activities, 10) the community eats fruit and vegetables irregularly, adapted to natural resources and the environment. Suggestions for this research; 1) the parties involved have to carry out a more comprehensive follow-up study, and 2) the community as beneficiaries should receive information, services, guidance and social assistance in a participatory, measurable and sustainable manner.
\end{abstract}

Key words: social mapping, clean and healthy behavior, indigenous, communities

\section{Introduction}

Health development as a part of Indonesian society development, is a basic right and a continuous reflection of the need to fulfill basic needs and to improve the welfare of Indonesian people in a fair and equitable manner. It's also an implementation to improve the quality Indonesia as a developed and democratic country. At this point, the degree and quality of public health is a measure of the success of development.

The degree of health is not only determined by the health services, but more dominantly is the condition of the environment and people's behavior. Scientists argue that the main factors that affect the degree of public health are the environmental conditions of individual, family, group and community behavior. Theoretically, the health status of an individual is closely related to its behavior, the better the behavior related to health, the better the health status (Ministry of Health, 2011). Efforts to change people's behavior in order to support the improvement of health status are carried out through a Clean and Healthy Life Behavior (PHBS) development program that has been implemented 
since 1996 (RI Ministry of Health, 2011). The PHBS coaching program launched by the government has been going on for a long time, but in reality the achievement of its success is still far from expectations.

In 2003 the Ministry of Health of the Republic of Indonesia established 10 indicators of PHBS in the household, namely childbirth assistance by health workers, exclusive breastfeeding to infants, health care insurance, availability of healthy toilets, clean water, suitability of house floor area with occupants, non-land floor, do not smoke, do physical activity, and consume vegetables and fruit. In 2007, the PHBS indicator in the Household was updated to; childbirth is assisted by health workers, gives babies exclusive breastfeeding, weigh babies every month, uses clean water, wash hands with soap, uses healthy toilets, eradicates mosquito larvae, eat fruits and vegetables every day, does activities every day and does not smoke inside the house (Indonesian Ministry of Health, 2011).

During 2013 - 2014, the percentage of residents of Asmat Regency who were sick tended to increase, from 28.20 percent in 2013 to 37.50 percent in 2014. The average duration of population illness also increased. In 2013 the average duration of sickness of the population was 3.69 days, increasing to 5.35 days in 2014. The average duration of illness described the amount of losses suffered by the population due to illness. The greater the value of this indicator, the higher the level of intensity of the disease suffered by the population and the greater the loss experienced. In other words there are 5.35 days that are not effective for use in productive activities (Regional Development Planning Board of Asmat Regency, 2015). This shows that the suboptimal health degree of the Asmat community is influenced by environmental conditions, community behavior, health services and genetics.

The above description draws the attention of researchers to examine further aspects of understanding problems and solutions relating to the profile of clean and healthy life behavior of the community. This is in line with Ackoff's statement (Edy Suharto, 2014) that the success of problem solving requires the right solution to the right problem. Identifying and analyzing problems is an important aspect of the community development and development process. One approach in handling social problems is social mapping, namely social profiling or profiling a community (Netting, Kettner and Mc Murty in Edy Suharto, 2014).

The area of study in this social mapping is Kampung Ulakin, Kolf Brasa District, Asmat Regency, Papua Province. The Asmat Regency Government and the Ministry of Social Affairs of the Republic of Indonesia have determined that Kampung Ulakin is one of the villages which belongs to the Remote Indigenous Community (KAT). Kampung Ulakin is one of the locations that receives social empowerment programs for remote indigenous communities according to the mandate of presidential regulation number 186 on social empowerment of remote indigenous communities and social minister regulation number 12 year 2015 concerning the implementation of social empowerment of remote indigenous communities.

Based on the description above, the formulation of the problem in this social mapping is: "What is the clean and healthy behavior profile of remote indigenous communities in Kampung Ulakin, Kolf Brasa District, Asmat Regency, Papua Province?"

\section{Research Methods}

Research method used in this social mapping is descriptive research. This social mapping was carried out in Kampung Ulakin, Kolf Brasa District, Asmat Regency, Papua Province in August - November 2017. To complete the data and information, a rapid assessment was also carried out in villages that were relatively close to Ulakin, namely Kampung Kapayap I, Auban, Butu Katnao and Kapayap II Kolf Brasa District.

All of respondents of this study were head of family heads (KK) recorded in Kampung Ulakin as many as 30 families from 36 families registered in Kampung Ulakin. Data collection was carried out by indepth interviews, focus group discussions and documentation relating to 10 PHBS indicators, namely 
delivery assistance by health workers, exclusive breastfeeding given to infants, health care insurance, toilet availability, clean water availability, suitability of house floor area with number of residents, the floor of the house is not land, do not smoke, do physical activity, and consume vegetables and fruit.

\section{Research Results and Discussion}

\section{The Condition of Ulakin Remoteness}

Ulakin is one of the villages in the Kolof Brasa District, Asmat Regency. Geographically, the location of Ulakin has the following boundaries; (a) to the north bordering the Bumu river, (b) to the south bordering Sirets river, (c) to the east bordering the Kampung Kapayap I, (d) to the west bordering the Salt river. To reach Ulakin location, facilities and travel time can be seen in the table below

Table 1: Travel Route to Kampung Ulakin District Kolf Brasa Asmat

\begin{tabular}{|c|c|c|c|c|c|c|c|c|c|}
\hline \multirow[t]{2}{*}{ No } & \multirow[t]{2}{*}{ Direction } & \multirow[t]{2}{*}{ Route } & \multirow{2}{*}{$\begin{array}{l}\text { Transportati } \\
\text { on Facilities }\end{array}$} & \multirow[t]{2}{*}{ Schedule } & \multirow[t]{2}{*}{ Time } & \multirow{2}{*}{$\begin{array}{l}\text { Cost } \\
(\mathbf{R p})\end{array}$} & \multicolumn{3}{|c|}{ Mobility } \\
\hline & & & & & & & $\mathbf{H}$ & $\mathbf{L}$ & VL \\
\hline \multirow[t]{9}{*}{1} & Jayapura - Timika & Air & Aircraft & Every day & 45 Minutes & 900.000 & $\mathrm{~V}$ & & \\
\hline & Timika - Agats & & & & & & & & \\
\hline & Timika - Agats & Sea & Aircraft & $1 \mathrm{x}$ a week & 45 Minutes & 800.000 & & $\mathrm{~V}$ & \\
\hline & Timika - Agats & Sea & Ship & $2 \mathrm{x}$ a month & 12 hours & 400.000 & & & $\mathrm{~V}$ \\
\hline & & Sea & Speedboat 85 PK & Rent & 6 Hours & 7.500 .000 & & & $\mathrm{~V}$ \\
\hline & Jayapura - Merauke & Air & Aircraft & Setiap hari & 60 Minutes & 700.000 & $\mathrm{~V}$ & & \\
\hline & Merauke - Agats & & & & & & & & \\
\hline & Merauke - Agats & Air & Aircraft & $1 \mathrm{x}$ a week & 85 Minutes & 1.000 .000 & & $\mathrm{~V}$ & \\
\hline & & Sea & Ship & $2 \mathrm{x}$ a month & 36 Hours & 700.000 & & & $\mathrm{~V}$ \\
\hline 2 & Agats - Suator & River & Speed 85 PK & Rent & 6 Hours & 6.750 .000 & & & $\mathrm{~V}$ \\
\hline \multirow[t]{2}{*}{3} & Suator - Ulakin & River & Katinting Boat & Rent & 6 Hours & 2.200 .000 & & & $\mathrm{~V}$ \\
\hline & Suator - Ulakin & River & Speedboat $40 \mathrm{P}$ & Rent & 2-3 Hours & 3.500 .000 & & & $\mathrm{~V}$ \\
\hline
\end{tabular}

Source: Results of Social Mapping (processed 2017)

Description: $\mathrm{H}=$ High; $\mathrm{L}=$ Less; $\mathrm{VL}=$ Very limited

In general, the trip from Jayapura to Agats, the capital of Asmat Regency, was mostly carried out through routes from Jayapura to Timika rather than Merauke. This is due to consideration of travel time, costs and technical requirements for official travel from the Asmat Regency Government. The remoteness condition of Kampung Ulakin can be seen in the table below.

Table 2: The condition of Kampung Ulakin, Kolof Brasa District, Asmat Regency

\begin{tabular}{cll}
\hline No. & \multicolumn{1}{c}{ Ethnographic State } & \multicolumn{1}{c}{ Data / information fields } \\
\hline 1. & Coordinate point & $05^{\circ} 14^{\prime} 003$ "BT $139^{0} 38^{\prime} 873^{\prime}$ LS \\
2 & Area Status & Production forest \\
3 & Number of KK / Soul & $36 / 162$ \\
& $0-4$ years & $14 \quad(8$ Male -6 Female $)$ \\
& $5-60$ years & $151(79$ Male -72 Female $)$ \\
4 & 61 years and above & $7 \quad$ (3 Male - 4 Female ) \\
5 & Social institutions & Kinship \\
6. & Community Group & Korowai / " Banano people " \\
7. & Habitat group & Very remote \\
8. & Livelihood & Forests - Watersheds - Outback \\
9. & Shape of the house & Hunting and gathering (traditional) \\
\hline
\end{tabular}




\section{Settlement pattern}

11. Religion / belief

12. Legal system

13. arts / culture

14. Difficulty factor

15. Amenities / village infrastructure

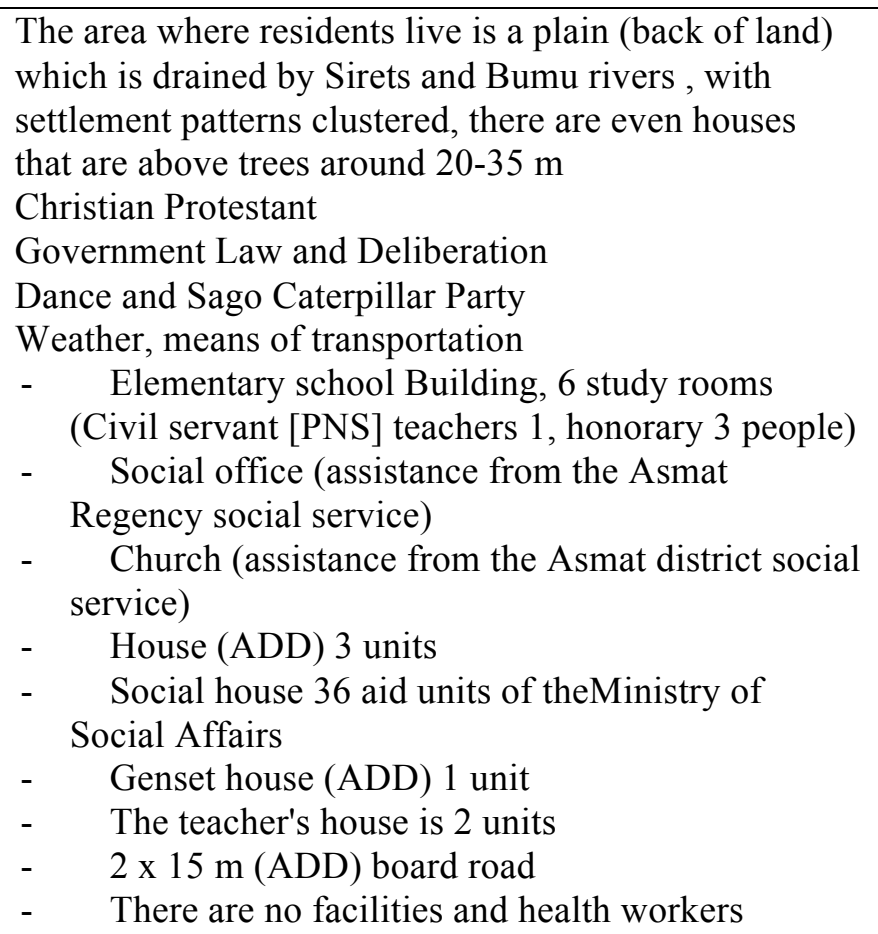

Source: Social Mapping, processed (2017)

The description above shows that Ulakin is a remote indigenous community (KAT) characterized by:

i. in the form of a small and homogeneous community

ii. Social institutions rely on kinship

iii. secluded geographically and relatively difficult to reach.

iv. Still living with a subsistence economic system.

v. Simple equipment and technology.

vi. Reliance on the environment and natural resources is relatively high.

vii. Limited access to social, economic and political services.

\section{Clean and Healthy Life Behavior}

Research on PHBS conducted in Kampung Ulakin, Kolf Brasa District, Asmat Regency uses 10 PHBS indicators, namely delivery assistance by health workers, babies are given exclusive breastfeeding, have health care coverage, toilet are available, clean water is available, suitability of house floor area with occupants, floors home is not land, does not smoke, does physical activity, and consumes vegetables and fruit.

Table 3: Achievement of PHBS with 10 Indicators in Kampung Ulakin Kolf Brasa District Asmat

\begin{tabular}{ccl}
\hline No. & \multicolumn{1}{c}{ Indicator } & \multicolumn{1}{c}{ Answer } \\
\hline 1 & Childbirth assistance by health & \\
& workers & $\begin{array}{l}\text { All Head of Family and Community stated that } \\
\text { childbirth assistance was carried out by their own } \\
\text { families who had never attended training for health }\end{array}$ \\
& workers. In the village of Ulakin and several nearby \\
& villages there were no officers and health facilities. \\
& Health workers carry out health service activities at \\
& the earliest once a month to Ulakin. Meanwhile, the \\
& distance from Ulakin village to the Puskesmas in the \\
& capital of Kolf Brasa was carried out with katinting \\
& for 4-5 hours. Each delivery of a pregnant woman,
\end{tabular}


community and/or family of Korowai in Ulakin and its surroundings prepares a hut measuring around $1 \mathrm{x}$ $1.25 \mathrm{~m}$. The hut as a place of delivery, usually a mother who will give birth accompanied by 1 or 2 female relatives occupy the place/hut a few days before giving birth. After giving birth, the hut was abandoned. Another place used for giving birth is a "bevak" house such as a halfway house that is used as a place to rest when hunting and gathering in the village of Ulakin.

2 Babies are given exclusive breastfeeding
Health Care Insurance

Toilet availability

$5 \quad$ Clean water availability
The provision of ASI is carried out by Ulakin residents on the basis of willingness, awareness and habits that have been carried out for generations. Ulakin people, especially mothers, are still very limited in their knowledge and attitudes towards ASI (Mother's Milk). Moreover, the presence of officers carrying out services is very rare, so that public knowledge is still far from expectations about ASI as a natural food in the form of fluids with sufficient nutritional content and is suitable for the needs of the baby, so the baby grows and develops well. The first breast milk is a clear yellowish liquid (colostrum), very good for babies because it contains immunity to diseases.

Other information needed by Ulakin people is related to the habit of breastfed babies as soon as possible no later than 30 minutes after giving birth to stimulate the milk to quickly come out and stop bleeding, give breast milk from both breasts alternately.

Moreover, the understanding of Ulakin residents who are still very limited is that in addition to ASI, ASASI (MP-ASI) is given in the form of pulverized and the amount according to the age development of the baby. Breastfeeding is continued until the baby is 2 years old.

The community does not have health insurance. Most community members do not have a population identity number (NIK). Only a few people have had (NIK) related to the process of resolving village (village) fund allocations, namely the village head, village secretariat, and three Teachers.

Every house of assistance from the social ministry has been equipped with a toilet (MCK). Most of them are not used properly. The Ulakin community still uses the forest area around the village for defecation.

5 houses of Ulakin residents from 36 houses built by the social ministry already have rain water tanks (reservoirs / water tanks). The Ulakin village government through the allocation of village funds has built a rainwater storage house with $6 @ 500$ liter water tanks.

Ulakin people have not used rainwater as a source of clean water (bathing and washing) they still use river water more for daily needs. 
of the house with the number eating, working, sitting, bathing, latrines, washing and of residents

cooking as well as other spaces. Ulakin simple house (36 $\mathrm{m} 2$ built by the Ministry of Social Affairs is seen already meet the minimum requirements as a healthy home, which is the space requirement per person is 9 $\mathrm{m}^{2}$, with the calculation of an average height of the ceiling is $2.80 \mathrm{~m}$. A healthy simple house allows residents to live healthy lives, and carry out daily living activities appropriately

7 The floor of the house is not land

Floor of all house of Ulakin people are made of wood / board. The main reason is due to natural conditions and factors in the habits or culture of the community about building a house. Other benefits are; (a) stress relief - giving $\mathrm{n}$ aroma therapy that brings the mind to reunite with the outdoors and the mind will be fresh again, (b) provide a balance of room temperature when hot or cold. Wood floors can provide a cool effect when the air is hot and provide a warm effect when the air is cold, (c) environmentally friendly, safe for child or the elderly, will not cause Rheumatic disease, gout or lumbago. Majority of Ulakin society have no experience to take care and cleaning the house.

8 Do not smoke Not all residents of Ulakin are smoking. The activities of Ulakin residents who smoke are carried out in places including inside the house, near toddlers and so on.

9 Doing physical activity

Ulakin people in their daily activities do hunting, gathering and other activities which are carried out as part of the habits and characteristics of the people who live around the forest, inland, and rivers.

10 Consume vegetables and fruit

The Ulakin community utilizes forest and river products for their daily needs, including vegetables (land spinach, fern leaves, cassava leaves, banana heart) and fruits (especially bananas). When eating vegetables, fruit and other foods, the community has not accustomed to always washing their hands with soap. They do handwashing activities, especially when they see their hands are considered dirty, not because of health reasons and demands.

Source: Results of Social Mapping (2017)

The data and information above shows that the achievement of PHBS in Kampung Ulakin is still far from expectations. The low achievement of households in clean and healthy behavior also occurred in Auban village, Kapayap I, Butu Katnao and Kapayap II, Kolf Brasa District, Asmat Regency. The lowest PHBS indicators are childbirth assistance by health workers, health care insurance, utilization of healthy toilets, and smoking habits in any places.

Some of the reasons that underlie and allow for the low level of knowledge, skills and the renewal of mental attitudes of community, as well as the limitations of socialization and readiness of stakeholders to realize the achievement of clean and healthy life behaviors, include:

i. Ulakin communities live in small groups with a limited level of communication with outside parties. In addition, the Ulakin community lives in a homogeneous unitary tribe.

ii. Ulakin community relies on kinship relations where their daily activities are still based on the relationship of blood and marital ties. The Existing local social custom include economic custom, health custom, legal custom, religious custom, believe custom, political custom, 
educational custom, scientific custom, space and time custom, social relations custom, kinship custom, social organization custom.

iii. Ulakin community is in the interior, forest and in the Bumu watershed which is relatively difficult to reach. This difficulty is reinforced by the limited transportation/transportation facilities and infrastructure, either from or to the Ulakin location. This condition affects and hinders the efforts of the government and outside parties in providing health and development services in an effective and integrated manner.

iv. The outcome obtained by Ulakin residents' economic activities are still limited to fulfilling their daily lives and their families. In general, they do not recognize the culture of saving (saving)

v. Ulakin residents still use simple equipment and technology to use and manage natural resources and their environment to fulfill their daily needs both in hunting, gathering and other production activities. They inherited the equipment and technology from generation to generation and / or limited purchases or assistance.

vi. Ulakin community is very dependent on natural environment. Their daily physical, mental and spiritual life are oriented to natural conditions or various natural events and phenomena.

vii. The logical consequence of remoteness to the availability of social, economic and political services are causing Ulakin residents facing obstacles and difficulties in fulfilling their basic needs and quality of life.

The implication of this condition, it seems that the related parties need to pay attention to and carry out various effort, patterns and mechanisms for fostering clean and healthy life behavior as follows:

i. Conduct discussions with stakeholders related to synchronization, harmonization and coordination of implementation of regulations and control of PHBS specifically in the household setting environment.

ii. Extending networks and strengthening the service process by providing facilitaties and health workers which in line with PHBS program at the district / sub-district level and other parties in the Asmat Regency.

iii. Formulate, implement and ensure the implementation of benefits of the PHBS program with coordination with district level up to the village level.

iv. Ensure and expand the implementation of training and / or PHBS development in the environment of educational institutions, workplaces, public places, health service facilities, village apparatus, social institutions and other parties.

v. Ensure and develop a model for updating the data base and registration of the Ulakin community and surrounding villages as beneficiaries of the PHBS program that matches the characteristics and dynamics of the Ulakin community as a remote indigenous community.

vi. Guiding, strengthening and developing an active role model of Ulakin leaders and people in; (i) planning, implementing, utilizing, and evaluating of PHBS processes, (ii) socializing and orientating the community understanding of contextual role, and (iii) manifesting the role of government as PHBS facilitators.

\section{Conclusion}

Condition of Kampung Ulakin, Kolf Brasa District, Asmat Papua is categorized as a remote, isolated and neglected community. The coverage of PHBS in Kampung Ulakin and several other nearby villages is still low, especially from aspects of childbirth assistance by health workers, health care insurance, utilization of toilet, and smoking habits in any places. Related parties should carry out further studies, plan models, implement and control all phases and procedures for PHBS development in stages, comprehensive and progressive. Ulakin community as beneficiaries should be fostered and 
prepared to obtain counseling, service, guidance and social assistance designed in a participatory, contextual and sustainable manner.

\section{References}

Ayu Khoirotul Umaroh, Heru Yuda Hanggara, dan Choiri, (2016). "Gambaran Perilaku Hidup Bersih Dan Sehat (PHBS) Di Wilayah Kerja Puskesmas Bulu Kabupaten Sukoharjo Bulan JanuariMaret 2015", dalam Jurnal Kesehatan, 1(1), Juni 2016: 25-31

Chazali, Husni, Situmorang, (2016). Dinamika Penyelenggaraan Jaminan Sosial di Era SJSN, Depok, Social Security Development Institute

Suharto, Edi. Membangun Masyarakat Memberdayakan Rakyat: Kajian Strategis Pembangunan Kesejahteraan Sosial dan Pekerjaan Sosial. Bandung, PT. Reflika Aditama, 2014

Sugiyono. Metode Penelitian Kuantitatif, Kulitatif dan R\&D. Bandung: Alvabeta, 2010.

Urip Wahyudin (2010). "Studi Kelayakan Pemberdayaan Komunitas Adat Terpencil Di Kampung Piramat" Distrik Fayit Kabupaten Asmat Papua". Makalah Semiloka Nasional Pengkajian Hasil Studi Kelayakan Pemberdayaan Komunitas Adat Terpencil Hotel Mercuri Batam, Kementerian Sosial RI. 5-8 Oktober 2009.

, (2014). Studi Kelayakan Pemberdayaan Komunitas Adat Terpencil Di Kampung Miop Distrik Suator dan Butu Katnao Distri Kolf Brasa Kabupaten Asmat Papua, Laporan, Dinas Kesejahteraan Sosial Asmat

, (2015). Studi Kelayakan Pemberdayaan Komunitas Adat Terpencil Di Kampung Auban dan Soray Distrik Kolf Brasa Kabupaten Asmat Papua, Laporan, Dinas Kesejahteraan Sosial Kabupaten Asmat

, (2016). Studi Kelayakan Pemberdayaan Komunitas Adat Terpencil Di Kampung Kapayap II Distrik Kolf Brasa Kabupaten Asmat Papua, Laporan, Dinas Sosial Kabupaten Asmat

Ministry of Health RI, (2011). Regulation of Minister of Health Number: 2269/MENKES/PER/XI/2011, Guideline for the development of clean and healthy life behavior (PHBS), Jakarta: Ministry of Health RI. 2011

Ministry of Social Affairs RI, (2012). Regulation of Minister of Social Affairs number 9 year 2012 about Remote Indigenous Communities (KAT) Empowerment.

Regency Government of Asmat, (2016). Strategic Plan of Regional Taskforce (SKPD) Asmat Health Service year 2016-2021.

, (2016). Strategic Plan of Regional Taskforce (SKPD) Asmat Social Affairs Service year $2016-2021$. 